\title{
EUROPEAN COMMON AVIATION AREA: AVIATION LIBERALISATION AND UKRAINE'S ACCESSION PROCESS
}

\author{
Kateryna Yu. Vodolaskova \\ $\mathrm{PhD}$ in Law, Associate professor of Law Faculty \\ of the National Aviation University \\ 1 Liubomyr Huzar Ave., Kyiv, Ukraine, 03058 \\ https://orcid.org/0000-0002-6133-822X \\ khusanova@gmail.com
}

\begin{abstract}
The signing of the Common Aviation Area (CAA) Agreement between Ukraine and the European Union (EU) is one of the priority task on the agenda in Ukraine. The implementation of the CAA Agreement is envisaged in the Association Agreement (2014) between the EU and Ukraine, the Action Plan of the Cabinet of Ministers of Ukraine1 (CMU) and the Strategic Development Plan of the aviation transport. Despite of the officially announced readiness of the Ukrainian side, the signing of the CAA Agreement has been postponed since 2013. Investigation of the external and internal problems for the integration of Ukraine into the CAA creates the topicality of this paper and leads to the purpose of the article. Purpose of the article is comprehensive study of the legal basis and background of ECAA, analyzing the neighborhood policies and hence, the determination of the main directions of incorporation of the EU civil aviation requirements and standards regarding market access, air traffic organization, flightsafety, the environmentand other issues in Ukraine'slegislation. Thearticle is based on usage of the general and special-legal scientific methods of cognition, as well as formal legal and dialectical approaches. Legal basement of this work, in particular, consists of:

a) the Association Agreement between Ukraine and the EU of 2014; b) National Program of Adaptation of the Legislation of Ukraine to the Legislation of the European Union (adopted by the Law of Ukraine on November 04, 2018, № 2581-VIII); c) the Strategic Plan for the Development of Air Transport (adopted by the Ministry of Infrastructure of Ukraine on December 21, 2015, Decree № 546) and d) the Action Plan to Prepare for the Introduction of a CAA of Ukraine with the EU and its Member States (adopted by the CMU on February 8, 2017, Order № 88-o) and other regulations. Results of the paper include the conceptual theoretic investigation to reveal external and internal problems on the way to the Ukraine's integration into the CAA of the EU, practical recommendations for the process of approximation of Ukraine's legislation to the EU's standards, and contribute to the liberalization of regulation of international air services.
\end{abstract}

\footnotetext{
${ }^{1}$ Government of Ukraine.
} 
Keywords: Common Aviation Area, liberalization of the aviation market, legislation implementation.

\section{INTRODUCTION}

The Common European Aviation Area Agreements are comprehensive air transport agreements. In accordance with these Agreements, the relevantaviation markets are gradually opened and integrated, an aviation area with common rules is developed, economic benefits for consumers are offered, as well as new opportunities for the industry are presented. The ECAA is a free trade area for aviation, in particular on flight safety, passenger protection, air carrier liability, environmental protection, competition and state aid.

\section{LITERATURE REVIEW AND PROBLEM STATEMENT}

This research is based on main scientific achievements of outstanding world scholars, who were successfully studying issues associated with creating legal fundamental sources for the establishment of the CAA from the very beginning, tasks and challenges of international aviation agreements, as well as practical and scientific researches of case studies worldwide on formation of air transportation policy and comparative study of certain zones of the world and process of approximation of national legislation. The research was possible to conduct based on the publications on a comprehensive analysis and historical perspective of the bilateral air transport agreements and Single European sky concept and European Common Aviation Area. Discussions and comparative study of the law policies of "open skies" for a new era in international aviation are the main background of the research due to the eagerness of Ukraine to become a member of a Common Aviation Area. According to the authors' opinion the way of aviation liberalization and opening of the air transport market process in Central and Eastern Europe could be the example and pointer for Ukraine's development of air transport towards the access to the European air transport market by means of signing the European Common Aviation Area Agreement in the nearest future.

The CAA Agreement between Ukraine and the EU was initialed on November 28, 2013, however, it was not sign up because of a dispute between Spain and the United Kingdom, which was referred to the Gibraltar airport. Despite of the delays with the signing of the CAA, the need to harmonize the aviation legislation of Ukraine with the EU's standards has not lost its importance. The necessity of changing the aviation legislation is stated in the association agenda between Ukraine and the EU and in the CMU's Resolution (2017), which proposes the Action Plan for introducing the CAA agreement and adapting Ukrainian legislation to the EU rules. Hence, the process of formation and development of legal and communicative basis for the EU-Ukraine CAA Agreement's signing and further implementation of European standards and rules into the aviation area need to be studied as well as challenges, advantages, disadvantages and main conceptual directions of legal work should be identified and revealed. 


\section{THE AIM AND OBJECTIVES OF RESEARCH}

The aim of this research is to make contribution into the Ukraine's access process into the ECA and study out the issue on challenges of conclusion of the CAA and tasks towards approximation of Ukraine's legislation to EU rules within the integration into the Common Aviation Area of European Union based on the experience of Balkan countries

To achieve the goal, authors set the following tasks to:

- reveal internal and external obstacles for Ukraine's accession to the EU CAA

- study of current state of legal framework of aviation policies and regulation.

- analyse the incorporation process of EU legislation into Ukraine's legislation: measures to adapt the legislation of Ukraine to the EU legislation in the field of aviation transport.

- justify ways of harmonization of Ukraine's legislation with the Council Directive 96/67/ EC of 15 October 1996 on access to the groundhandling market at Community airports.

- evaluate the role of state stakeholders in the process of Ukraine's accession to the CAA and determine their scope of obligations in approximation to EU standards.

\section{SINGLE EUROPEAN SKY: FROM ITS CREATION TO CURRENT CHALLENGES}

European integration took place essentially on the ground. At first glance, this appears to be a completely unproblematic, almost trivial and alternative statement. But if one realizes that the European airspace is also an object to be regulated, it becomes clear that there is also a European integration in the air or that this can be a desideratum like its counterpart on the ground. If the manifest border stations have long been a thing of the past, they are in the air up to the present literally limiting.

The EU regulatory initiative "Single European Sky" (SES) has set itself the task of standardizing the European sky (Havel; 1997). However, it took until the turn of the millennium until one could speak of inclusion in the political agenda of the European Union (EU) in the narrower sense.

\subsection{Historical background}

Around 1960, with the founding of the European Organization for the Safety of Air Navigation, it is possible to begin to speak of a genuinely European airspace policy for the first time.

The first stage covers the longest period from 1960 to 1999. It took the longest period due to the fact the comparatively ambitious founding of Eurocontrol will remain the only European initiative for a long time, provided that this attribute is actually assigned at this point, because the airspace itself is almost assumed to be regulated by national governments (Butcher, 2002). Only when the signs (more precisely: delay statistics) intensify that the measures that allow Eurocontrol's limited powers to fizzle out at national borders, the European Community institutions feel obliged to bring airspace politically to the European level.

In June 1992 the European Council of Ministers agreed the Third Aviation Liberalisation Package. The Third Package was the culmination of a gradual process of liberalisation of the Community air transport market to which Member States committed themselves in 1986. 
The decision to "create a single market in aviation formed part of the move to a single internal market across the whole range of economic activity, as embodied in the Single European Act" (Hobe, 2018). The signing of the Single European Act and the renewed commitment to eliminating barriers to commerce and resource movement created EU-wide markets in a broad range of goods and services, including civil aviation.

The second stage began from the initiative about the creation of the SES was launched in 1999 to improve the performance of air traffic management (ATM) and air navigation services (ANS) improve a better integration of the European sky. Significant benefits are expected from the SES project as, compared to 2004, the SES could (once completed around 2030-2035) triple airspace capacity and halve the cost of air traffic management, improve safety tenfold, and reduce the impact of aviation reduce the environment (Havel, 2011).

\subsection{Legal basis}

The Single European Act (SEA) sought to revise the Treaties of Rome establishing the European Economic Community (EEC) and the European Atomic Energy Community.

This was in order to add new momentum to European integration and to complete the internal market (an area with no internal borders and in which there is free movement of goods, persons, services and capital) by 1 January 1993.

The SEA amended the rules governing the operation of the European institutions and expanded the powers of the then European Community in a number of policy areas.

By creating new Community competencies and reforming the institutions, the SEA opened the way to further political integration and economic and monetary union that would be enshrined in the Treaty on European Union (the Maastricht Treaty).

The Single European Sky (SES) initiative was started in 2000 by the European Commission after the delays to flights in Europe (in 1999).

The SES package is aimed to:

- Enhance safety and efficiency of air transport in Europe;

- Reduce delays by improving the use of scarce airspace and airport resources;

- Improve services and reduce cost to air transport passengers by reducing the fragmentation of the air traffic management in Europe;

- Improve the integration of military systems into the European air traffic management system.

The legislative package adopted in 2004 comprises four basic regulations, which reinforce safety and foster the restructuring of European airspace and air navigation services. The regulations provide the framework for the creation of additional capacity and for improved efficiency and interoperability of ATM system in Europe.

The Framework regulation (EC No 549/2004) - laying down the framework for the creation of the single European sky;

The Service provision regulation (EC No 550/2004) - on the provision of air navigation services in the Single European sky;

The Airspace regulation (EC No 551/2004) - on the organisation and use of airspace in the Single European sky;

The Interoperability regulation (EC No 552/2004) - on the interoperability of the European Air Traffic Management network (EUROCONTROL, 2004). 


\subsection{Brexit: UK-EU relations in the aviation sphere}

While being a member of the EU, airlines of UK had access to the ECAA (till the end of the transition period, that is till December, 312020 (Wright, 2020).

The ECAA was established in 2006 as a follow-up to the Single Aviation Market and is under the control of the European Aviation Safety Agency (EASA), and its legislation is applied by the European Court of Justice (ECJ).

The EU has also negotiated horizontal agreements with 17 other non-ECAA countries. Horizontal agreements (including the EU-USA Open Skies Agreement and the EU-Canada Air Transport Agreement) cover areas such as access rights for airlines, passenger rights and investment (Swinnen, 1997).

The UK Government identified the three most likely options for future UK arrangements with the EU. These are:

- Membership of the European Economic Area (EEA), which is the model currently followed by Norway and which ensures full access to the Single Market;

- Ad hoc bilateral arrangements, similar to the bilateral agreements between the EU and Switzerland (in fact the aeronautical relationships between UE and Swiss Federation are ruled by a special agreement signed in 1999); and

- WTO relationship (e.g. no special/formal arrangement with the EU).

- Through these and the ECAA, the UK flights have access to 44 countries, accounting for about $85 \%$ of all of Britain's international air traffic (Di Peio, 2017).

\section{THE ESTABLISHMENT OF THE EUROPEAN COMMON AVIATION AREA: NEIGHBORHOOD POLICY}

In 2006 the ECAA was established as a single market in aviation services defined by bilateral agreements between EU countries.

Based on the EU acquis communautaire and the EEA, the ECAA actually hoped to achieve the goal of liberalizing of the air transport market by giving any company from an ECAA member state permission to fly between any airport within the ECAA (including the ability of a foreign company to operate domestic flights).

The ECAA agreement was signed by the European Community itself, almost all of the $27 \mathrm{EU}$ members, Norway, Iceland, as well as Balkan countries: Albania, Bosnia and Herzegovina, Croatia, Macedonia, and Kosovo (UNMIK as Kosovo representative under Security Council resolution 1244). Slovakia and Latvia after joining the EU sign it respectively on June 13th, 2006 and June 22nd, 2006. Finally, Serbia signed on June 29th, 2006 and Montenegro on July 5th, 2006 [9].

\subsection{The ECAA and the Western Balkans}

In June 2006 the EU and the countries of South Eastern Europe signed a memorandum on the setting up of the ECAA by 2010. From the date of the signing of this agreement the ECAA has extended to the Western Balkans. It implies full liberalization of the cross-border traffic between the signatories, an adoption of the aviation legislation and comprehensive restructuring of the sector at the national level. It is expected this agreement leads to rapid 
growth of the traffic, encourages foreign investment in the aviation sphere and performs an important role to catalyze wider regional integration. However, to reap the benefits, the Western Balkans countries will need to implement an ambitious reform agenda in a short period of time including reform implications for governments and donors.

Such extension of the European single market for air industry to South East Europe gave a support for business travel, tourism and broader regional integration. The ECAA agreement was initialed in December 2005 and signed in June 2006 (Mölders, 2012). It obliges all signatories to approximate the legislation to the EU's standards in air transport industry.

It implies the following steps:

- implementation of legislation for the market access liberalization, traffic rights and fares;

- standards on slot allocation and airport ground handling;

- norm on state aid and competition;

- security and safety standards;

- environmental regulations and consumer rights related to aviation and

- the acquis pertaining to air traffic management (ATM) and the SES.

Bilateral air service agreements (ASAs) between countries have traditionally regulated cross-border air traffic rights. Principles stipulated in the 1944 Chicago Convention and notion of national sovereignty over airspace are the main basis for ASAs. Bilateral ASAs define frequency and names of service of certain routes, capacity (e.g. used type of aircraft), airlines ('designated' airlines) and the price. ASAs may also contain clauses on airport charges and taxation. "Freedoms of the air" are the traffic rights granted by ASA, they are as follows:

- Freedom Nr.1 (flight over another country) and freedom Nr. 2 (a technical stop in another country) do not provide for freight or passenger flows between two countries that are parties to the ASA.

- Freedoms Nr. 3 and Nr. 4 allow the carriage of passengers / cargo to and from destinations in the two involved countries, but exclude domestic transport or connections with a third country.

- Freedom Nr. 5 allows an airline to take passengers or cargo on a stop in another country before disembarking them in a third country.

- Freedom Nr. 6 allows to carry passengers or cargo between another country and a third country through their own (home) country.

- Freedom Nr. 7 allows to operate flights between another country and a third country without any stopping in their own (home) country.

- Freedom Nr. 8 (referred also as 'cabotage') and freedom Nr. 9 (on true domestic) allow domestic flights within another country, with or without a cross-border flight (Hobe, 2004).

The implementation of the ECAA agreement took place in three phases. During the 1st phase, rights of freedoms Nr. 3 and Nr. 4 were completely liberalized. This meant all airlines licensed within the ECAA area obtained the possibility to fly to and from their own countries to any other ECAA destination, without bandwidth or frequency restrictions. The second phase involved a liberalization of the freedom Nr. 5, and allowed airlines to pick up passengers 
at a stop in the other country before disembarking them in a third country. Before a partycountry may move to the second phase of the ECAA, however, it was necessary to introduce a basic package of the aviation legislation, which mainly concerns security and safety regulations. The third phase included the liberalization of freedoms Nr. 6-8 and complete transposition of the aviation legislation. No clear target dates were set for the first 2 phases, and each country could progress at its own pace once it met the necessary conditions [12].

\subsection{Neighbourhood agreements of CAA}

Inspired by the experience of enlargement to the East, much of the academic debate on EU's external relations and the European Neighbourhood Policy comes up with external influences in terms of the Union's ability to stimulate third countries' adaptation to EU rules and norms [Lavenex, 2008].

The CAA Agreements provide the adoption by neighbouring EU partners of the part of the Acquis, which contains the European aviation regulations, starting with requirements to safety. Opening of the market and progressive harmonization of regulatory acts are carried out consistently and technical assistance is provided to support these partner countries in taking the necessary measures. The CAA is implemented on the basis of comprehensive aviation agreements, which promote general economic, tourism and trade relations. Negotiations on such a comprehensive agreement may begin as soon as a neighboring country demonstrates its clear readiness and commitment for joining the CAA.

The EU has signed agreements on CAA with the Western Balkans, as well as Morocco, Georgia, Moldova, Jordan and Israel. The first neighbourhood agreements were concluded with partners from the Western Balkan and Morocco in 2006 and have been applied starting from the date of signature. Similar agreements with Jordan and Georgia were signed in 2010. After that agreements with Moldova (2012) and Israel were signed (2013). Moreover, negotiations on an aviation agreement with Ukraine have been held and it is planned to sign it in the near future. As for relations with other neighboring countries, negotiations are underway with Tunisia, Azerbaijan and Lebanon. After all, the total European Aviation Area can cover up to 50-55 states with a total population of up to 1 billion inhabitants (European Commission, 2019).

The Communication from the Commission to the Council and the European Parliament Communication was adopted and setting out a renewed cooperation in transport policy with

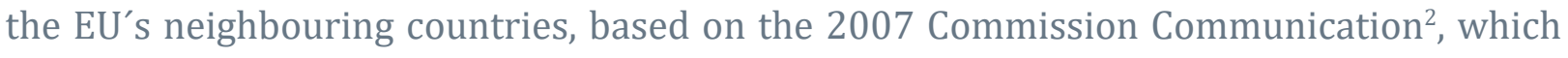
focused on infrastructure aspects. It covers both: the enlargement countries ${ }^{3}$ and the ENP ${ }^{4}$, with primary accent on the ENP countries. The high level of transport cooperation already attained with enlargement countries can be a model for improving transport connections with other neighbouring regions ${ }^{5}$.

\footnotetext{
$\overline{2}$ Extension of the major trans-European transport axes to the neighbouring countries, COM(2007) 32, 31.1.2007

${ }^{3}$ Candidate countries: Croatia, the former Yugoslav Republic of Macedonia, Montenegro, Turkey. Potential candidates: Albania, Bosnia and Herzegovina, Serbia, Kosovo (under UNSCR 1244/99).

${ }^{4}$ ENP East: Armenia, Azerbaijan, Belarus, Georgia, Moldova, Ukraine; ENP South: Algeria, Egypt, Israel, Jordan, Lebanon, Libya, Morocco, Occupied Palestinian Territory, Syria, Tunisia.

${ }^{5}$ Iceland, Norway, Russia and Switzerland are not covered by this Communication
} 
The Commission has recently reviewed the ENP, the single policy framework for the EU's relations with its neighbouring partner countries ${ }^{6}$ and offered a new response to a changing neighbourhood. According to this response, transport cooperation will be adapted to the needs of each sub-region. The EU will apply a higher level of differentiation in the transport sector depending on each country's ambition and readiness to integrate more closely with the EU. EU support, in the form either of financing infrastructure links or of expanding market access, will depend on a progress of the neighbouring countries at this issue (European Commission, 2011).

\section{PROCEDURE OF THE UKRAINE'S ACCESSION INTO THE ECAA}

The liberalization of the aviation market is inevitable as Ukraine prepares to sign an 'open sky' agreement with the EU. In order to approach to this aim, it is crucial to approximate the Ukrainian air transport legislative norms to the European standards and international treaties based on a real step towards implementation of the state plans and programs. Transport infrastructure must be developed to promote Ukraine's fast economic and social development, taking into account national needs and interests.

Ukraine (as other post-Soviet countries) is intending to make the transformation towards a consolidated democratic system, functioning market economy and efficient democratic state with extensive welfare policies. It is not necessary for Ukraine to 'reinvent the wheel' in this matter. "Whatever action is performed by a great man, common men follow in his footsteps. And whatever standards he sets by exemplary acts, all the world pursues" (Prabhupada, 1989).

Therefore, studying of the positive experience of Balkan and EaP countries in the sphere of the CAA will become a basis for Ukraine's intentions towards preparations for the CAA Agreement signing and further implementation of its standards and regulations.

Even though the readiness was officially announced to the Ukrainian side, the signing of the CAA Agreement has been postponed since 2013. The main reason for the postponement of the signing of this Agreement in 2014-2016 is the scarcity of consensus between the United Kingdom and Spain on the wording of Article 31, Territory, of Article 2, „Definition” of the Agreement, regarding the territorial status of Gibraltar (Rajoy, 2019).

\subsection{Legal Basis of negotiation process}

In accordance with the clauses of Annex XXII of the Association Agreement (AA) between Ukraine and the EU Members Ukraine undertakes to progressively approximate its legislation to the EU legislation, in particular, in the sphere of aviation industry according to the requirements, stipulated in the CAA Agreement, which was initialed on November 28, 2013 in Vilnius and has not yet come into force. However, in accordance with sub-item (ii) "Aviation" of item 7.4 "Transport" of Section 7 "Other Sectoral Issues" Part III "Operational Part" of the EU-Ukraine Association Agenda, the Parties shall cooperate to prepare Ukraine for the implementation of the EU acquis provided for in the relevant annexes to the AA:

6 COM (2011) 303, 25.05.2011 
- continuation of implementing measures to align Ukraine's aviation legislation with the EU legislation;

- implementation of the EU aviation standards, based on the CAA Agreement after its signing and strengthening administrative capacity in the sphere of aviation management;

- support and further development of cooperation with EASA on flight safety issues, including the approximation of certification and oversight systems for providers air navigation services to the relevant EU system.

In accordance with Article 5 "Basic principles of regulatory Cooperation" of the CAA Agreement Ukraine must take the necessary measures to incorporate into the Ukrainian legal system and to implement the requirements and standards of acts of EU legislation listed in Annex 1 to the CAA Agreement, in accordance with the transitional arrangements set out in Article 33 of the Transitional Arrangement.

For example, such regulatory acts in accordance with Annex 1 concerning air navigation service providers are: Regulation (EU) No 2018/1139 of the European Parliament and of the Council of 4 July 2018 on common rules in the field of civil aviation and establishing a European Aviation Safety Agency, supplementing Regulation (EU) No 2111/2005, (EU) No 1008/2008, (EU) No 996/2010, (EU) No 376/2014, and the repeal of Regulation (EU) No 552/2004, (EU) No 2016/2008 of the European Parliament and of the Council and of Council Regulation (ESC) No 3922/91; Commission Regulation (EU) No 2017/373 of 01 March 2017 laying down common requirements for air traffic management and air navigation service providers and other functions of the network manager and their supervisory system, and repealing Regulation (EU) No 482/2008, (EU ) No 1034/2011, (EU) No 1035/2011 and the supplement to Regulation (EU) No 677/2011 (ASSOCIATION AGREEMENT, 2014).

Hence, the implementation of the CAA Agreement is envisaged by the AA between Ukraine and the EU of 2014, the Governmental Action Plan of 2016, and the Strategic Plan for the Development of Air Transport for the Period up to 2030 [18].

\subsection{Current situation}

Today the EU Council has mandated the European Commission to open negotiations with Ukraine to develop a common aviation area. The aim is to further deepen aviation relations with Ukraine following the signature of similar agreements with the Western Balkan countries and Morocco.

On December 18-19, 2019 in accordance with Article 467 (3) of the Association Agreement the Parliamentary Committee of the Association, having discussed recent developments in Ukraine and EU-Ukraine relations, and exchanged views on the priorities of future events, both parties agreed on the Final Statement and Recommendation that stress the need to enhance trade and economic cooperation and to continue trade liberalization, including through the swift conclusion of Ukraine-EU Common Aviation Agreement (ASSOCIATION AGREEMENT, 2014).

Therefore, the basic conditions for integration into European and world transport systems are:

- the approximation of the legislation to the European norms and standards in the sphere of air transport,

- compliance with key international agreements and conventions, 
- development of international transport corridors, the whole aviation infrastructure,

- safety and environmental friendliness of transportation.

6.2.1. European standards' adoption in Ukraine. Ukraine has already started to implement EU norms and standards into its legislation, that is, it has started to implement the clauses of the CAA Agreement even before it is signed, unilaterally by voluntary basis.

The CAA requirements for passenger rights, the division of aviation into state, civil and general aviation ("small aviation"), aviation security, environmental protection, etc. were all taken into account during the adoption of the Air Code of Ukraine in 2011.

An agreement signed in 2017 between the State Aviation Service and the European Commission on the convergence of certification systems stipulated that, over the next 5 years, joint work will be continued on achieving convergence of certification systems in the areas of primary airworthiness, maintenance of airworthiness and maintenance of its aircraft components. As a result, in particular, few Aviation Rules of Ukraine, which comply with the EU Regulations, staff training were developed and adopted. In 2017, the State Aviation Security Program for Civil Aviation was adopted, a number of licensing conditions and rules were approved. One of the major innovations of the CAA Agreement is Ukraine's accountability for EASA aircraft certification. Ukraine should provide mechanisms for conducting EASA standardization inspections and audits. However, the certificates, licenses and other technical documentation must be issued by the national authorities of Ukraine. For example, UkSATSE has been audited in 2018 by EASA and received the certificate, which was necessary to maneuver the aircraft when approaching Uzhgorod airport. However, the appropriate mechanism for regular EASA checks has not yet been developed (Kosse and Kulchytska, 2018).

The issue of opening up the groundhandling services market has not yet been resolved. Developed in February 2017 and revised in November 2018, the Draft of the Aviation Rules "Access to the Groundhandling Services Market at the Airport” has not been considered by the Verkhovna Rada?.

Meanwhile, the groundhandling market at airports remains monopolized by individual companies. For example, in November 2018, the Antimonopoly Committee of Ukraine found violations of antitrust laws by Kyiv (Zhulhany) airport and Master-Avia LLC, which concluded a general ground service agreement and ousted other companies from this market. In 2017, Boryspil Airport was fined for UAH 13 million for abusing of its monopoly position in the market of specialized airport services in the area of airport ground services. Thus, work on harmonization of Ukrainian and European legislation in the sphere of air transportation is underway. However, it is difficult to assess the degree of harmonization since such monitoring is not carried out (Final Statement, 2019).

Even the Government's Priority Action Plan for 2019 aligns Ukrainian legislation with European aviation standards within one year after the CAA Agreement entered into force.

7 Parliament of Ukraine. 
6.2.2. Stages of accession period. According to the CAA Ukraine has to incorporate the EU legislation and requirements in the sphere of civil aviation relating to market access, air traffic organization, flight safety, environment and other issues into its legislation. It is planned to provide such incorporation in two stages, and thus two transitional periods are distinguished.

Once the CAA Agreement is signed, the first transition period will begin. It will allow Ukrainian and EU air carriers to fly between any points in the EU and in Ukraine.

Ukraine will be involved as an observer in the work of the committee responsible for the distribution of slots at EU airports. Simultaneously, the process of the harmonization and implementation of the Ukraine's legislation will go on. Successful completion of this tasks will allow the start of the second transition period.

During the second transitional period, the EU recognizes crew certificates issued by Ukraine; groundhandling service providers will be able to operate in the territory of the other Party; Ukraine will be involved as an observer in the work of the committee, which determines which airlines are prohibited from operating within the EU.

After Ukraine organizes its airspace in accordance with the EU requirements, the CAA will be fully operational. EU airlines will be able to fly between Ukrainian cities; Ukrainian airlines may fly between EU cities provided that the flight is part of the service serving the point in Ukraine (thus, the Agreement is asymmetrical). The EU will begin to recognize the certificates issued by Ukraine for air traffic management and air navigation services (Kosse and Kulchytska, 2018).

Therefore, the most important and significant effect of signing the CAA Agreement will be the mutual "opening" of the sky for Ukrainian and European carriers. Passengers and airports benefit from an increase in the number of flights between cities of Ukraine and the EU, as well as increase of competition between airlines. Politically, Ukraine will strengthen its position as a European player by gaining access (at least as an observer) to the decisionmaking process of European aviation authorities.

\subsection{Main directions for further contribution onto the fostering of the accession process}

Main steps towards Ukraine's accession into the ECAA should be directed to making complex and fundamental analysis of the whole scope of European norms and standards, which have to be implemented by Ukraine in the aviation sphere to become a full-fledged and real member of the CAA based on the concluded Agreement.

First of all, it is crucial to make contribution into the realization of the Action Plan to Prepare for the Introduction of a CAA of Ukraine with the EU and its Member States (adopted by the CMU on February 8, 2017, Order № 88-o), namely, of the clause on:

a. preparation of implementation plans and enforcement of EU legislative acts set out in Section 2 of Annex III of the CAA Agreement project;

b. Development and adopting of the Aviation Rules for aerodrome certification based on Commission Regulation (EU) No 139/2014;

c. Development and adopting of the Aviation Rules for the performance of air operations based on Commission Regulation (EU) No 965/2012; 
d. Development and adapting of the Aviation Rules for Civil Aviation Flight Crews based on Commission Regulation (EU) No 1178/2011 (Regulation (EC) № 550, 2004).

\subsubsection{Further directions and perspectives towards Ukraine' accession to ECAA are:}

- Incorporation of the EU requirements and standards in the sphere of civil aviation relating to market access, air traffic organization, flight safety, environmental environment and other issues into the Ukraine's legislation.

- Focus on the implementation of the CAA Agreement in the sphere of EU technical regulations and directives and expect the right moment to resume active negotiations on the signing of the Agreement.

- Organizing the signing of a Memorandum with the European Commission on the convergence of certification systems.

- Fulfillment of the conditions for the transition to the second transition period specified in the SAP Agreement, namely the incorporation into the national legislation of Ukraine of the EU regulations and directives set out in Section 2 of Annex III of the SAP Agreement.

- Simplifying the Ministry of Justice's regulatory compliance process acts that will allow EU regulations and directives to be adopted by the package and without prolonged adaptation.

- Separation of areas of responsibility of the Ministry of Infrastructure and the Civil Service in the process of incorporation of EU legislation.

- To make a detailed plan on legal changes and influence to ground handling at airports of Ukraine within the CAA

- To justify ways of harmonization of Ukraine's legislation with the Council Directive 96/67/EC of 15 October 1996 on access to the groundhandling market at Community airports (Council Directive 96/67/EC, 1996).

- To evaluate the role of state stakeholders in the process of Ukraine's accession to the CAA and determine their scope of obligations in approximation to EU standards.

\section{DISCUSSION OF THE RESEARCH RESULTS}

Ukraine's orientation towards European community displays in various sphere, particularly, in air transport sector and the legal basement of this vector, in particular, consists of:

a. the Association Agreement between Ukraine and the EU of 2014;

b. National Program of Adaptation of the Legislation of Ukraine to the Legislation of the European Union (adopted by the Law of Ukraine on November 04, 2018, № 2581-VIII);

c. the Strategic Plan for the Development of Air Transport (adopted by the Ministry of Infrastructure of Ukraine on December 21, 2015, Decree № 546) and

d. the Action Plan to Prepare for the Introduction of a CAA of Ukraine with the EU and its Member States (adopted by the CMU on February 8, 2017, Order № 88-0) and other regulations.

Main objectives of the special authorities of Ukraine in the sphere of access to the ECAA as well as main discussions of this research results are to form and define the priority directions 
of development of the aviation transport industry according to the intention of Ukraine to become a part of the CAA, in particular:

- bringing aviation infrastructure in line with international requirements;

- implementation of European standards and requirements in the field of flight safety;

- integration with the European Aviation Transport System through the gradual conclusion of the Agreement between the EU and Ukraine on a Common Aviation Area and participation in an air traffic organization program in a single European airspace;

- deepening Ukraine's participation in pan-European aviation organizations: the European Civil Aviation Conference, the European Aviation Safety Organization, the European Aviation Safety Agency;

- implementation of the core components of the EU Single European Sky concept. It is proposed to sign a technical agreement between the State Aviation Administration and the European Aviation Safety Agency (EASA) on the Common Aviation Area;

- adoption and implementation of the State Flight Safety Target Program in accordance with ICAO International Standards;

- adaptation of Ukraine's regulatory framework to ICAO and EU requirements and standards.

\section{CONCLUSIONS}

The scale of the future European international air transport market will also be largely scaled by the practical shape of European competition policy.

The EU made importantsteps towards opening markets, developing a regulated competition shape and unleashing the aviation industry's potential. There will be a regular need for policy evolution as well as streamlining and modernization of the regulatory framework in order to maintain and enhance this success. A revision of the regulatory framework is currently being discussed with all interested parties, in order to consolidate the basis for an open, competitive, innovative, safe and sustainable aviation market in Europe. It is hoped that it could serve as a useful reference for consideration by partner countries and regions (Sichelschmidt; Wolf, 1993).

As a natural consequence of the abandonment of the concepts of national markets and national carriers within the EU, the creation of the single market is now starting to have an external effect and an EU external aviation policy is emerging.

A genuine internal market for air transport has thus been created across the European Union. But the geographical extension of the single market goes further. In June 2006, the EU and its Member States signed the agreement establishing the European Common Aviation Area (ECAA). This agreement integrates partner countries in South-East Europe into the single market.

The ECAA partner countries also adopted EU air transport laws and regulations. In parallel, these air transport markets were gradually liberalized and integrated into the EU single market (ICAO, Assembly, 1996).

In the future, the Common Aviation Area could be further extended to include Ukraine and other neighboring countries, in particular in the Mediterranean region. 
After full implementation of the Agreement Ukrainian airlines will have the opportunity to use unlimited commercial rights to conduct transportation services between Ukraine and the EU and between any EU member-states, provided that the flight is served at some point in Ukraine. The EU airlines will have unlimited commercial rights to conduct transportation services to Ukraine and inside Ukraine. Moreover, such liberalization of the aviation market will be mutually beneficial for both sides of the agreement.

\section{REFERENCES}

Havel Brian F. (1997). In search of open skies: law and policy for a new era in international aviation: a comparative study of airline deregulation in the United States and the European Union. Kluwer Law International

Butcher, Louise. Aviation: European liberalisation, 1986-2002. Retrieved from https://researchbriefings. files.parliament.uk/documents/SN00182/SN00182.pdf $+\& c d=2 \& h l=u k \& c t=c l n k \& g l=u a$

Hobe Stephan (2018). Review: Peter Paul Fitzgerald: A Level Playing Field for "Open Skies”: The Need for Consistent Aviation Regulation, Mit: Benjamyn I. Scott, In: ZLW, 67, 1, 192-195.

Havel Brian F. (2011). Rethinking the General Agreement on Trade in Services as a Pathway to Global Aviation Liberalisation. 45 IRISH JURIST, 47-94.

Single European Sky (SES). EUROCONTROL. SKYbrary. Retrieved from https://www.skybrary.aero/index. php/Single_European_Sky_(SES)

Wright, Georgina (2020). UK-EU future relationship: aviation. Retrieved from https://www. instituteforgovernment.org.uk/explainers/future-relationship-aviation

Swinnen B. M. J. (1997). An Opportunity for Transatlantic Civil Aviation: from Open Skies to Open Markets? Journal of Air Law and Commerce. 63.

Filippo Di Peio. Brexit and the Single European Aviation market: first comments and reflections. Retrieved from https://www.lexology.com/library/detail.aspx?g=5a22ecc1-8bf5-4252-8b6b-5afbc0ad3969

External Aviation Policy - A Common Aviation Area with the EU's neighbours. Retrieved from https:// ec.europa.eu/transport/modes/air/international-aviation/external-aviation-policy/external-aviationpolicy-common-aviation_en

Marc Mölders (2012). Der Himmel über Europa Eine Fallstudie zur Genese des „Single European Sky“ Dortmund/Bielefeld, im November 2012. Retrieved from https://pub.uni-bielefeld.de/ download/2694346/2694349

Hobe Stephan (2004). Perspektiven für den internationalen Luftverkehr nach den “Open Skies” Urteilen des EuGH, in: Proceedings des11. Luftverkehrsforums der DVWG, Workshop: „Luftverkehrsmärkte der Zukunft - Entwicklung des Luftverkehrsraums USA-EU: Welche Chancen hat Deutschland? “, Frankfurt 4.2.2004, Schriftenreihe der DVWG, Bd. 273, 98-120.

The European Common Aviation Area and the Western Balkans: Domestic Reforms and Regional Integration in Air Transport. European Commission - World Bank. Retrieved from http://documents1. worldbank.org/curated/en/390621468255858328/pdf/42006optmzd0EC1r0Transport01PUBLIC1.pdf

Sandra Lavenex (2008). A governance perspective on the European neighbourhood policy: integration beyond conditionality? Journal of European Public Policy. 15:6 938-955 DOI: 10.1080/13501760802196879

Communication from the Commission to the Council and the European Parliament The EU and its neighbouring regions: A renewed approach to transport cooperation. Retrieved from: https://eurlex.europa. eu/LexUriServ/LexUriServ.do?uri=COM:2011:0415:FIN:EN:PDF

Bhagavad-Gita (1989). As It Is (Paperback) Mass Market Paperback - Deluxe Edition, June, 1989. By A C Bhaktivedanta Swami Prabhupada

Mariano Rajoy. Gibraltar is an anachronism and the last colony in Europe. The Telegraph. Retrieved from: http://www.telegraph.co.uk/news/worldnews/europe/gibraltar/10335859/Mariano-Rajoy-Gibraltar-isananachronism-and-the-last-colony-in-Europe.html

Association agreement between the European Union and its Member States, of the one part, and Ukraine, of the other part. Official EN Journal of the European Union. 29.5.2014. L 161/3

Action Plan. European Neighborhood Policy. Approved by the Cabinet of Ministers of Ukraine on February 12, 2005. Approved by the Cooperation Council between Ukraine and the European Union on February 21, 2005. URL: http://zakon4.rada.gov.ua/laws / show / 994_693 
Iryna Kosse, Kateryna Kulchytska (2017). Aviation Vector of Eastern Partnership: Approximation of National Legislations to the EU Laws. Evaluation of the progress in Ukraine, Moldova, and Georgia. https:// europewb.org.ua/wp-content/uploads/2018/02/PRINT_engl_zvit_The-Eastern-Partnership-AirTransport-Vector_EWB.pdf

EU-Ukraine Parliamentary Association Committee. Tenth Meeting 18-19 December 2019 (Strasbourg). Final Statement and Recommendations pursuant to Article 467(3) of the Association Agreement. Retrieved from https://iportal.rada.gov.ua/en/news/News/186811.html

Regulation (EC) № 550/2004 of the European Parliament and of the Council of 10 March 2004 On The Provision of Air Navigation Services in the Single European Sky (the service provision Regulation) (Text with EEA relevance) Official Journal of the European Union. - L 96, 47, 10-19.

Council Directive 96/67/EC of 15 October 1996. Retrieved from https://eur-lex.europa.eu/legal-content/ EN/ALL/?uri=CELEX\%3A31996L0067

Sichelschmidt, Henning; Wolf, Hartmut (1993): Die Liberalisierung des EG-Luftverkehrs: Entwicklung, Stand und Perspektiven, Die Weltwirtschaft, ISSN 0043-2652, Springer, Heidelberg, 2, 167-185.

International Civil Aviation Organization. Information Paper. Assembly - 36TH SESSION. Executive Committee. Retrieved from https://www.icao.int/Meetings/AMC/MA/Assembly\%2036th\%20Session/ wp096en.pdf 